\title{
Effect of binder and drum speed on hematitic fines balling
}

\author{
Fernando Rodrigues da Cunha ${ }^{1}$ \\ José Aurélio Medeiros da Luz ${ }^{2}$ \\ Pedro Henrique Neuppmann ${ }^{2 *}$ (1)
}

\begin{abstract}
Determination of the physical properties of pellets is of great industrial importance since they are parameters that will allow a better use of the fines in the plants. Several studies relating different process variables with the pellet properties produced can be found in the literature, but it is still very difficult to predict the particle size distribution of the agglomerates of a new formulation only with the knowledge of its properties. In this study, the ore characterization was performed, evaluating the effect of the rotational speed of the drum and the performance comparison between two binders during green pellets granulation. Decrease of average diameter of the pellets with the use of a carboxymethylcellulosebased binder (Peridur 330, $0.4 \mathrm{~kg} / \mathrm{t}$ ratio) was observed, in comparison with the conventional binder, bentonite $(5 \mathrm{~kg} / \mathrm{t}$ ratio). Bentonite-containing mixture has showed slightly lower porosity and lower permeability, also indicating a higher resistance of the pellets formed.
\end{abstract}

Keywords: Granulation; Iron ore; Carboxymethylcellulose; Bentonite.

\section{Efeito do ligante e da velocidade de rotação no pelotamento de finos hematíticos}

\section{Resumo}

A determinação de propriedades físicas das pelotas é de grande importância industrial uma vez que são esses parâmetros que permitem um melhor aproveitamento dos finos nas usinas. Vários trabalhos relacionando diferentes variáveis de processo com as propriedades da pelota produzida podem ser encontrados na literatura, porém é muito difícil prever quantitativamente a distribuição granulométrica dos aglomerados de uma nova formulação somente com o conhecimento de suas propriedades mineralógicas, químicas. Neste estudo foi realizada a caracterização do minério, avaliado o efeito da velocidade de rotação do tambor granulador e a comparação de desempenho entre dois aglomerantes. Houve redução do diâmetro médio dos grânulos com a utilização de aglomerante baseado em carboximetilcelulose (Peridur 330, sob dosagem de $0.4 \mathrm{~kg} / \mathrm{t}$ ) em comparação com bentonita (sob dosagem de $5 \mathrm{~kg} / \mathrm{t}$ ). As pelotas contendo bentonita apresentaram porosidade ligeiramente menor e menor permeabilidade, indicando também uma maior resistência das pelotas formadas.

Palavras-chave: Pelotamento; Minério de ferro; Carboximetilcelulose; Bentonita.

\section{Introduction}

Fine particles entail processing problems in various and different areas of the industry. Especially in the mining and metallurgical industry, the ore fines have been the cause of recovery losses, cost increases, increase of the volume of the tailings produced, reduction of the product grades, reduction of the useful life of deposits and even undertaking unfeasibility. Therefore, granulation processes have become very important tool for enabling tailings and fines exploitation in the mineral industry.
Granulation, or balling, is the process of forming aggregates by agglomerating particles with the sprinkling of a binding liquid while they are revolved in a rotating drum or disc, fluidized bed or high shear mixer. Some advantages of agglomeration include minimization of dust generation and the improvement of the bulk material flowability, easing its handling and storing. Further advantages are the stabilization of homogeneous mixtures of particles which could not otherwise be done in another way and the

${ }^{\prime}$ Laboratório de Modelamento e Pesquisa em Processamento Mineral, Universidade Federal de Goiás - UFG, Catalão, GO, Brasil.

${ }^{2}$ Departamento de Engenharia de Minas, Universidade Federal de Ouro Preto - UFOP, Ouro Preto, MG, Brasil.

*Corresponding author: phneuppmann@gmail.com 
increase of the bed permeability, which is very desirable in metallurgical processing.

There are several phenomena acting simultaneously in the process, which makes their understanding complex. This phenomenon is divided into three groups: wetting, nucleation and distribution of the binder, consolidation and growth of the granule, attrition and breakage [1].

The first step of the granulation is the addition and dispersion of the binder to form the nuclei. The binder liquid is added in the form of spray on the bed of moving particles. If the liquid does not easily wet the particles or if the wetting speed rate is slow, large wet agglomerates will form on the bed surface. The shearing forces within the bed may be strong enough to break such agglomerates of wet material in order to better distribute the liquid [2]. The liquid binds the particles through the combination of capillary pressure, surface tension and viscous forces, until more stable bonds are formed [3].

Nucleation provides a size distribution of cores constituted by weakly bound parent particles. Under suitable wetting conditions, this distribution will be narrow and closely related to the droplet size distribution. Poor wetting and inadequate nucleation cause wide grain size distribution and often low quality pellets. The nucleation process is strongly influenced by the liquid spray characteristics [2].

The use of bentonite as a binder in the granulation of iron ores is widely used in the current pelletizing processes. These binders control the moisture of the concentrates and significantly improve the characteristics of the pellets. The main disadvantage of the use of bentonite is the contamination of the product with the siliceous gangue, since the product remains are present in all stages of the metallurgical transformation, lowering the system basicity [4].

Another product used in agglomeration is carboxymethylcellulose, formed by the reaction between cellulose and caustic soda, promoting an etherification reaction. Carboxymethylcellulose has several applications in the mineral industry, being used primarily as a drilling fluid, depressant in froth flotation circuits and as a binder and water retainer in pelletizing [5]. The use of the carboxymethylcellulose compound Peridur 330 has been studied for the granulation process. However, its industrial use is not yet widely known due to its high cost when compared to alternative products such as bentonite and lime [6]. It is important to know the dispersion parameters of the slurry, through the correct dosage of hydrated lime in the granulation process, since the coagulation of the ore would lead to the production of a dried pellet in its interior, yet with high surface moisture. This phenomenon would make the pellets brittle and with low mechanical strength.

Nevertheless, high particle dispersion would lead to instability of the system, making it difficult to form pellets, thus drawing in pellets with high humidity and low resistance [7].

The growth (a mass accretion process) may be through the coating of existing cores from new particulate material, which increases the mass of the pellets and can be induced by the rolling mechanism, in a snowball effect. Another mechanism of granule growth is by coalescence, when the collision between two grains occur and they get together to form a single larger grain. For the coalescence to happen, the energy of the impact must be absorbed during the collision [8].

Balling by tumbling drums is affected by several parameters and is influenced by the drum diameter, rotational velocity and slope angle, also affecting the residence time of the particles inside the drum [9]. Low speeds of drum rotations cause the pellets to slip from the top of the drum to the base. Higher rotational speeds cause the grains to start rolling and the agglomeration probability increases. It has been suggested by Walker [9] that the optimal granulation rate is around $50 \%$ of the critical velocity, at which the material is loaded to the top of the drum by centrifugal force.

Pellets formed through the nucleation and growth processes can break down generating a number of fragments, or they can wear out by friction and generate a series of fine particles. The complexity of the breakage models goes from binary systems to models represented by the breakage functions and the selection of particle size distributions, in addition to empirical models [4].

Moraes [10] evaluated the application of several reagents in the pelletizing of iron ore and observed that the binders Peridur 330 and bentonite reduce the dispersion degree of pellet feed slurries, finding values of $2.02 \%$ for the Peridur 330 and $4.53 \%$ for the bentonite. For the ore in the absence of reagents, a degree of dispersion of $3.33 \%$ was observed. The clarified appearance of the supernatant at the end of the assay time was also observed, suggesting the agglomeration of the particles due to the effect of Peridur 330.

The main response variables in the balling process are the average size of the pellets, the particle size distribution and the resistance properties of the green pellets by drop test [11].

\section{Materials and methods}

The sample used was collected in a processing plant in the Iron Quadrangle (important Brazilian mineral province) and then it was quartered to obtain the aliquots for the tests.

\subsection{Characterization of the ore}

The particle size distribution was studied by wet sieving of the sample in the range from $105 \mu \mathrm{m}$ to $38 \mu \mathrm{m}$. In order to complete the size analysis, the material passing through the $38 \mu \mathrm{m}$ sieve was analyzed in a Bettersize 2000 laser granulometer. The determination of the major chemical elements was done by X-ray fluorescence in a Philips PANalytical branded equipment, MagiX model with PW 2540 automatic sampler and $2.4 \mathrm{~kW}$ rhodium tube. The X-ray diffractogram was obtained using a Shimadzu 
model XRD-6100 and the data analysis was done through comparisons with the database standards with the aid of the software XRD-6100/7000 version 7.00. The determination of the specific surface was carried out on a QuantaChrome branded equipment, model NovaWin2, using nitrogen at $77.35 \mathrm{~K}$ and adopting a BET adsorption isotherm. Specific mass determination assays were performed using a helium pycnometer, model Ultrapyc 1200 e version 4.00 from QuantaChrome. The thermogravimetric analysis of the sample was performed on a Mettler Toledo equipment, Star System model using an inert atmosphere of $\mathrm{N}_{2}$ at a flow rate of $6 \times 10^{-6} \mathrm{~m}^{3} / \mathrm{s}(60 \mathrm{~mL} / \mathrm{min})$ at a heating rate of $10^{\circ} \mathrm{C} / \mathrm{min}$ between $303.15 \mathrm{~K}\left(30^{\circ} \mathrm{C}\right)$ and $1.223,15 \mathrm{~K}\left(950{ }^{\circ} \mathrm{C}\right)$. The peaks of the obtained thermogram will be compared with values predicted in the literature [12].

\subsection{Granulation or balling tests}

Balling tests were performed on a rubber-lined granulator drum of $258 \mathrm{~mm}$ in diameter (providing a critical speed of $83 \mathrm{rpm}$ ) by $294 \mathrm{~mm}$ in length, made of $7 \mathrm{~mm}$ thick stainless-steel sheets and supported on two rotating rolls, one of them was free and the other was driven by a set of pulleys and an electric motor with speed adjusted by a frequency inverter.

Two granulation mixtures were evaluated. The first one consisted of $5 \mathrm{~kg}$ of ore, $25 \mathrm{~kg} / \mathrm{t}$ of hydrated lime $\left(\mathrm{Ca}(\mathrm{OH})_{2}\right)$ and $5 \mathrm{~kg} / \mathrm{t}$ of bentonite, while the second one was composed of $5 \mathrm{~kg}$ of ore, $25 \mathrm{~kg} / \mathrm{t}$ of hydrated lime and $0.4 \mathrm{~kg} / \mathrm{t}$ of Peridur 330, a carboxymethylcellulose based binder, from Akzo Nobel. It is important to stress that this work aimed to evaluate the granulation process and not the complete pelletizing chain (balling, sizing and induration, generally performed at the temperature range of $1.200{ }^{\circ} \mathrm{C}$ to $1.350^{\circ} \mathrm{C}$ ); consequently, it was not necessary to introduce coke into the blends mentioned above.

These mixtures were added dry in the drum, thus initiating the water aspersion spraying and then it was stirred for the predetermined time. Once the timing was over, the granulation process was stopped and the pellet was allowed to dry in an oven at $100{ }^{\circ} \mathrm{C}$. The rotational speed of the drum was varied from $40 \mathrm{rpm}$ ( $48 \%$ of the critical speed) to $48 \mathrm{rpm}$ (58\% of the critical speed), with the other variables remaining unchanged. Similarly, in the tests in which the influence of residence time was evaluated, all other variables were kept constant.

The water spray was produced using a continuous manual jet sprayer with graduated reservoir. Moisture measurement of the formed aggregates was performed in order to determine the water absorption within the aggregate and to evaluate this influence on the strength of the granules and on the size of the aggregates.

The resistance of the pellets produced was measured by the method called "drop test", where 20 granules were randomly selected and dropped against a steel plate from a height of $0.45 \mathrm{~m}$ until they break, for each condition analyzed. Another parameter of measured resistance was the weight necessary for the rupture of the pellets for each condition tested. This test consisted in the measurement through a scale of the weights added on the pellets until they collapsed. This essay was carried out for 10 granules under each test conditions.

Micrographs were taken with an optical microscope to identify the presence of pores inside the pellets produced, followed by an evaluation of the porosity and permeability values. The determination of the porosity was done by determining the actual and apparent specific mass of the pellets. A number of 15 measurements were taken to determine the apparent specific mass of each binding component. The ore actual specific mass was obtained through the knowledge of the specific masses of each constituent. For the calculation of the apparent specific mass, test specimens were prepared by carefully flattening raw pellets with the aid of sandpaper until they were shaped as small parallelepipeds whose edges were measured with a ruler. From the dimensions of the specimen edges, their volumes were calculated. Given the actual specific masses of the solids $\left(\rho_{\mathrm{s}}\right)$ and apparent $\left(\rho_{\text {bulk }}\right)$, the porosity calculation was performed, according to the Equation 1 below.

$$
\in=\frac{\rho_{s}-\rho b u l k}{\rho_{s}}
$$

Permeability constants were estimated using the D'Arcy's law, shown in Equation 2, where the values of the permeability constant for each balling condition were compared. For these tests, $0.01 \mathrm{~m}$ thick parallelepipeds were made by the same procedure explained above for the porosity tests.

A simplified permeabilimeter, shown in Figure 1, was assembled to allow the permeability determination of the probes without their collapse by immersion in water, since the green pellets obviously had not been submitted to sintering (induration step). The specimens (1) were positioned at the upper end of a cylinder (3) connected by a latex hose (4) to a glass pipette (5), initially containing water up to a reference height on its graduated scale (pipette's internal diameter was equal to $\phi_{2}=0.0108 \mathrm{~m}$ ). Silicone (2) was used to seal the side facets of the test probe. The effective cross-sectional area of the permeabilimeter was equal to $2.27 \times 10^{-4} \mathrm{~m}^{2}$ (corresponding to diameter $\phi_{1}=0.0170 \mathrm{~m}$ ). The water head loss in the pipette bottom outlet (and that due to the friction of the liquid in the pipette wall) was negligible in relation to the head loss caused by the air entrance through the specimen's interstices at the top of apparatus.

In line with this procedure, the permeability coefficient was obtained by expliciting this parameter from D'Arcy equation, which relates the head loss through the fluid passage (in laminar regime) through the porous medium (Equation 2). 


$$
k=\frac{Q v(t) \times L \times \eta}{A \times \Delta p(t)}
$$

Where:

$k$ - Permeability constant $\left[\mathrm{m}^{2}\right]$;

$Q v(t)$ - volumetric fluid flow rate as a function of time $\left[\mathrm{m}^{3} / \mathrm{s}\right]$;

$L$ - Thickness of specimen (probe) [m];

$\eta$ - Dynamic viscosity of the fluid (air) [Pa.s];

$A$ - Effective transverse area of the porous medium $\left[\mathrm{m}^{2}\right]$; $\Delta p(t)$ - Driving pressure difference in the time $\mathrm{t}[\mathrm{Pa}]$.

The dynamic viscosity of the air was determined by the empirical from Sutherland, according to Garland et al. [13]. For a temperature of $295.15 \mathrm{~K}\left(22^{\circ} \mathrm{C}\right)$, it results in a dynamic viscosity of $1.837 \times 10^{-5} \mathrm{~Pa}$.s.

The experiments consisted in determining the average volume flow rate during the drainage time, measuring the displacement (descent) of the water column in the pipette. Assuming isochoric steady flow, the flow rate of percolated air was equal to the drained water flow from the pipette, since the sealing system avoided any unwanted air intake. The liquid column inside the pipette diminished over time. Correspondingly, the driving pressure also decreased. Thus, it is necessary to integrate the differential equation that describes this system, the Equation 3.

$$
Q_{v}(t)=\frac{k \times A \times \Delta p(t)}{L \times \eta}=\frac{A_{1} \times d y}{d t}=\frac{A_{2} \times d z}{d t}
$$

In the preceding equation $\boldsymbol{A}_{1}$ and $\boldsymbol{A}_{2}$, respectively, are the cross-sectional areas of the sample holder cylinder (of the effective diameter $\phi_{1}$ ) and the pipette (of the effective diameter $\phi_{2}$ ). The elemental displacement $\boldsymbol{d} z$ is the lowering of the liquid column in the pipette after an elementary time interval $\boldsymbol{d} \boldsymbol{t}$. Analogously, $\boldsymbol{d} \boldsymbol{y}$ would be the elemental advance of the percolated air front corresponding to $d t$. From the Equation 3 we have the Equation 4:

$$
d y=\frac{A_{2}}{A_{1}} \times d z=\frac{\frac{\pi}{4} \times \phi_{2}}{\frac{\pi}{4} \times \phi_{1}} \times d z=\left(\frac{\phi_{2}}{\phi_{1}}\right)^{2} \times d z
$$

Considering that the operating pressure will be given by the weight of the liquid column in the pipette divided by the area, thus, the following Equation 5 holds:

$$
A p(t)=-p_{i} \times g \times z(t)
$$

Applying Equation 4 and 5 in Equation 3 and separating the variables for the integration, the equation gives this result the Equation 6:

$$
\frac{k \times A_{I} \times \rho_{L} \times g}{\eta \times L} \int_{0}^{t} d t=-A_{I} \times\left(\frac{\phi_{2}}{\phi_{I}}\right)^{2} \times \int_{z_{0}}^{z_{f}} \frac{d z}{z(t)}
$$

In which the new coming letters stand for the following physical quantities:
$\mathrm{L}$ - Specific mass of the liquid $\left[\mathrm{kg} / \mathrm{m}^{3}\right]$;

$\boldsymbol{g}$ - Acceleration of gravity $\left[\mathrm{m} / \mathrm{s}^{2}\right]$;

$z_{f}$ - Height of the water column inside the pipette at the final instant $[\mathrm{m}]$;

$\boldsymbol{z}_{0}$ - Height of the water column inside the pipette at experiment beginning $[\mathrm{m}]$.

Eliminating $\boldsymbol{A}_{\boldsymbol{1}}$ from the two terms and proceeding to integration, finally the following explicit equation for the permeability coefficient results Equation 7:

$$
k=\frac{\eta \times L}{\rho_{L} \times g \times t} \times\left(\frac{\phi_{2}}{\phi_{I}}\right)^{2} \times \ln \left(\frac{z_{0}}{z_{f}}\right)
$$

\section{Results and discussion}

\subsection{Sieving, chemical and mineralogical characterization}

The chemical analysis quantified, in terms of oxides, the composition of the ore sample, being hematite $(73.05 \%)$ and quartz $(11.31 \%)$ the major components (Table 1). Several other oxides were identified, with aluminum and manganese

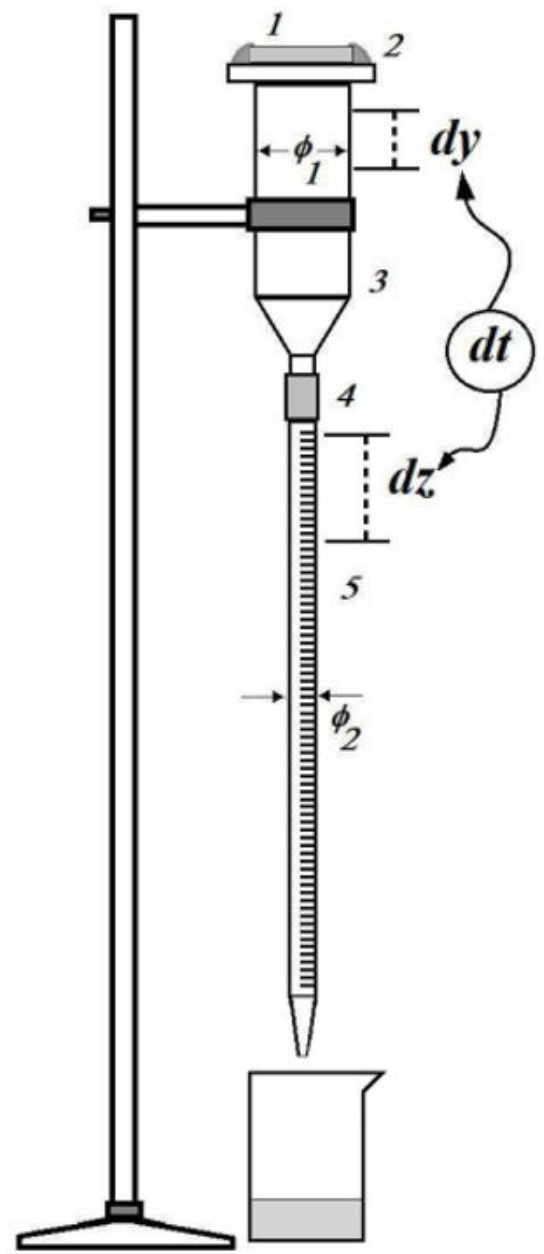

Figure 1. Simplified apparatus for determination of the permeability. 
being in the highest proportions, while magnesium, phosphorus, titanium and calcium were seen in low concentrations.

Weissenborn et al. [12] studied the mass loss for pure samples of minerals present in iron ores and identified some peaks of mass loss. At temperatures below $373.15 \mathrm{~K}\left(100^{\circ} \mathrm{C}\right)$, a mass loss occurs due to the surface moisture of the samples. The mass loss can also occur due to the transformation of the goethite and kaolinite phases. The transformation of goethite occurs between $548.15 \mathrm{~K}\left(275^{\circ} \mathrm{C}\right)$ and $628.15 \mathrm{~K}$ $\left(355^{\circ} \mathrm{C}\right)$ and for the kaolinite, between $768.1 \mathrm{~K}\left(495^{\circ} \mathrm{C}\right)$ and $918.1 \mathrm{~K}\left(645^{\circ} \mathrm{C}\right)$. The mass losses for pure goethite and pure kaolinite are respectively $10.1 \%$ and $14.0 \%$.

$$
\begin{aligned}
\mathrm{FeOOH} & \rightleftarrows \mathrm{Fe}_{2} \mathrm{O}_{3}+\mathrm{H}_{2} \mathrm{O} \\
\mathrm{Si}_{4} \mathrm{Al}_{4}(\mathrm{OH})_{8} \mathrm{O}_{10} & \rightleftarrows \mathrm{Si}_{4} \mathrm{Al}_{4} \mathrm{O}_{14}+4 \mathrm{H}_{2} \mathrm{O}
\end{aligned}
$$

The result of the thermogravimetric analysis showed three peaks of mass loss (Figure 2). The first can be attributed to the presence of moisture in the sample, resulting in a mass loss of $1.5 \%$ between temperatures of $303.15 \mathrm{~K}\left(30^{\circ} \mathrm{C}\right)$ and $373.15 \mathrm{~K}\left(100^{\circ} \mathrm{C}\right)$. The second peak can be related to the presence of goethite, evidencing a mass loss of $1.0 \%$ between $493.15 \mathrm{~K}\left(220^{\circ} \mathrm{C}\right)$ and $623.15 \mathrm{~K}\left(350^{\circ} \mathrm{C}\right)$, indicating approximately $10 \%$ of goethite in the sample. Lastly, the third peak should be related to the kaolinite phase transformation, causing a mass loss of $0.4 \%$ between $723.15 \mathrm{~K}\left(450{ }^{\circ} \mathrm{C}\right)$ and $973.15 \mathrm{~K}\left(700^{\circ} \mathrm{C}\right)$, which corresponds to approximately $3 \%$ of kaolinite in the sample [12].

The sample had a BET specific surface area of $1,570 \mathrm{~m}^{2} / \mathrm{kg}$. The mean true density was $4,502 \mathrm{~kg} / \mathrm{m}^{3}$ (sample standard deviation of $11 \mathrm{~kg} / \mathrm{m}^{3}$ ), which is compatible with the chemical analysis obtained.

The X-ray diffractogram (Figure 3) shows the presence of hematite and quartz as major phases, as identified in the chemical analysis and goethite as minor mineral. In that figure, the discrete peaks corresponding to values of 2 -theta equal to $21.39^{\circ}, 33.29^{\circ}$ and $36.58^{\circ}$ have been assigned to the minority presence of goethite, whose respective crystallographic values in standard tables are $21.24^{\circ} ; 33.28^{\circ}$ and $36.62^{\circ}$ (which correspond to Bragg interplanar spacing of 4,180 x $10^{-9} \mathrm{~m}$; $2,690 \times 10^{-9} \mathrm{~m}$ and $2,452 \times 10^{-9} \mathrm{~m}$ ). Despite the presence of several elements in the chemical analysis, any of their crystalline compounds was detected, naturally because they are in minority and below the detection threshold.

Particle size analysis indicated that the sample consisted entirely of particles below $149 \mu \mathrm{m}$ and that $23 \%$ of the sample consisted of particles below $10 \mu \mathrm{m}$ (Figure 4). It can be seen that $d_{80}$ is about $85 \mu \mathrm{m}$, while $\mathrm{d}_{50}$ is around $40 \mu \mathrm{m}$.

\subsection{Granulation in tumbling drum}

The evaluation of the effect of drum rotation speed and type of binder on the particle size distribution of the pellets indicated that larger granules were formed when the bentonite-hydrated lime mixture was used (Figure 5). One can see when using the bentonite the $d_{50}$ of the pellet was between $30 \mathrm{~mm}$ and $40 \mathrm{~mm}$, the $\mathrm{d}_{80}$ was between $40 \mathrm{~mm}$ and $50 \mathrm{~mm}$. In contrast, for the experiments performed using Peridur 330, a narrowing of the particle size distribution was observed, the $\mathrm{d}_{50}$ was around $20 \mathrm{~mm}$, the $\mathrm{d}_{80}$ was around $30 \mathrm{~mm}$ and no pellet larger than $50 \mathrm{~mm}$ was obtained.

The results also show there was a tendency to increase the mean diameter of the pellets and a greater regularity of size when the drum rotation was reduced from $48 \mathrm{rpm}$ to $40 \mathrm{rpm}$. This behavior can be attributed to the increase of the breaking mechanism with increasing collision energy between the pellets and against the drum wall.

Several particle size distribution models were tested for the products generated in the granulation. The best fit (with squared Pearson's coefficient of correlation: $\mathrm{r}^{2}=0.999$ ) was obtained for the Rosin-Rammler-Sperling-Benett distribution [14]. The equation as a function of the median and sharpness index or modulus ( $\boldsymbol{n}$ ) holds by equating $50 \%$ to the cumulative mass fraction through the median opening $\left(\boldsymbol{x}_{50}\right)$ is shown in Table 2.

Measurement of the moisture in the products showed that the compound Peridur 330 at the speed of $48 \mathrm{rpm}$ generated an aggregate with lower humidity (9.3\%) instead of $13.0 \%$ for $40 \mathrm{rpm}$. Reverse behavior was observed for the addition of

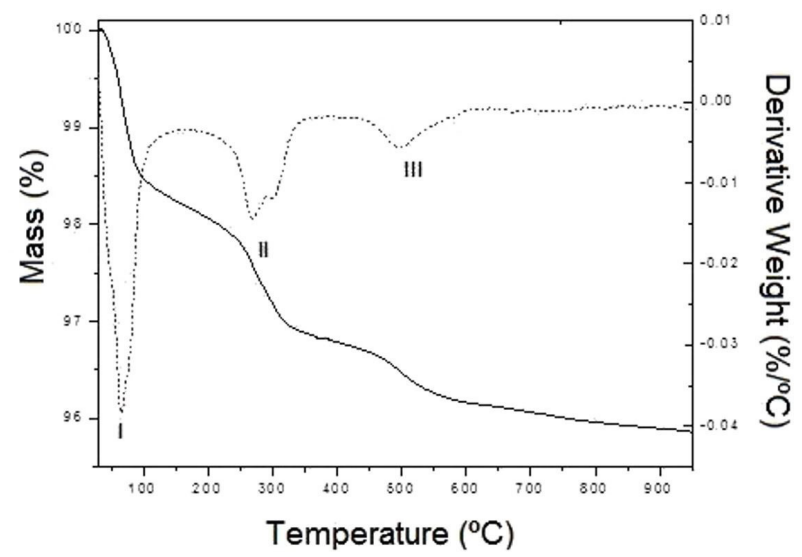

Figure 2. Thermogram of the analyzed sample. Notes: I: moisture; II: goethite; III: kaolinite.

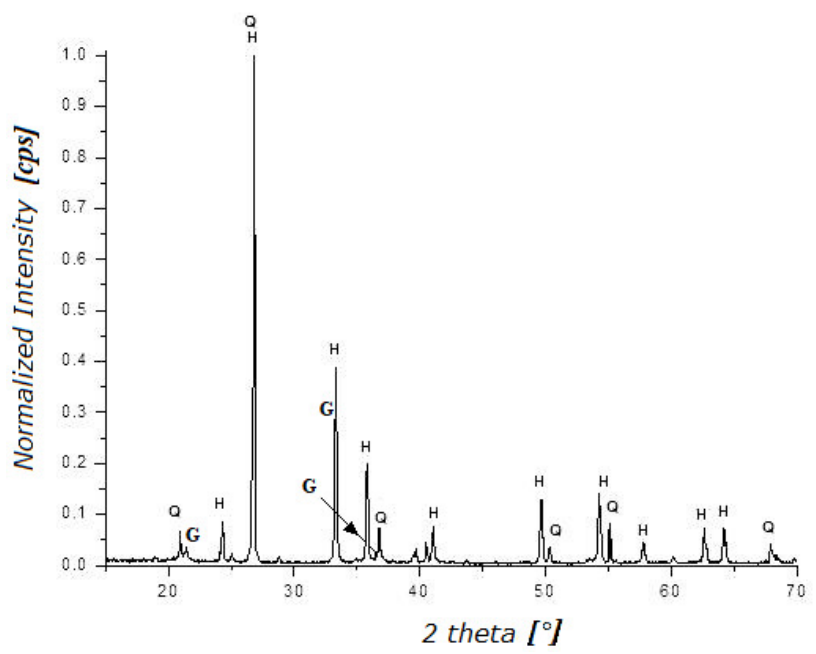

Figure 3. X-ray diffractogram. Notes: H: hematite; Q: quartz; G: goethite. 
Table 1. Chemical X-ray Fluorescence Analysis

\begin{tabular}{cccc}
\hline Analyzed Oxides & [\%] & Analyzed Oxides & [\%] \\
\hline $\mathrm{Fe}_{2} \mathrm{O}_{3}$ & 73.05 & $\mathrm{P}_{2} \mathrm{O}_{5}$ & 0.36 \\
$\mathrm{SiO}_{2}$ & 11.31 & $\mathrm{TiO}_{2}$ & 0.17 \\
$\mathrm{Al}_{2} \mathrm{O}_{3}$ & $\mathrm{CaO}$ & 0.11 \\
$\mathrm{MnO}_{2}$ & 9.20 & Others & 2.81 \\
$\mathrm{MgO}$ & 2.07 & & \\
\hline
\end{tabular}

Table 2. Parameters of the Rosin-Rammler-Sperling-Benett model

\begin{tabular}{|c|c|c|c|c|}
\hline Parameters Equation & \multicolumn{2}{|c|}{ Peridur 330} & \multicolumn{2}{|c|}{ Bentonite } \\
\hline$Y_{\text {pass }}=1-\exp \left[\ln \left(\frac{1}{2}\right) \times\left(\frac{x}{x_{50}}\right)^{n}\right]$ & $48 \mathrm{rpm}$ & 40 rpm & $48 \mathrm{rpm}$ & $40 \mathrm{rpm}$ \\
\hline Median size: $x_{50}(\mathrm{~mm})$ & 19.69 & 21.73 & 32.97 & 37.46 \\
\hline Sharpness index (modulus): $n$ & 3.77 & 3.14 & 4.01 & 3.21 \\
\hline Pearson's coefficient of determination: $r^{2}$ & $99.96 \%$ & $99.79 \%$ & $99.86 \%$ & $99.96 \%$ \\
\hline
\end{tabular}

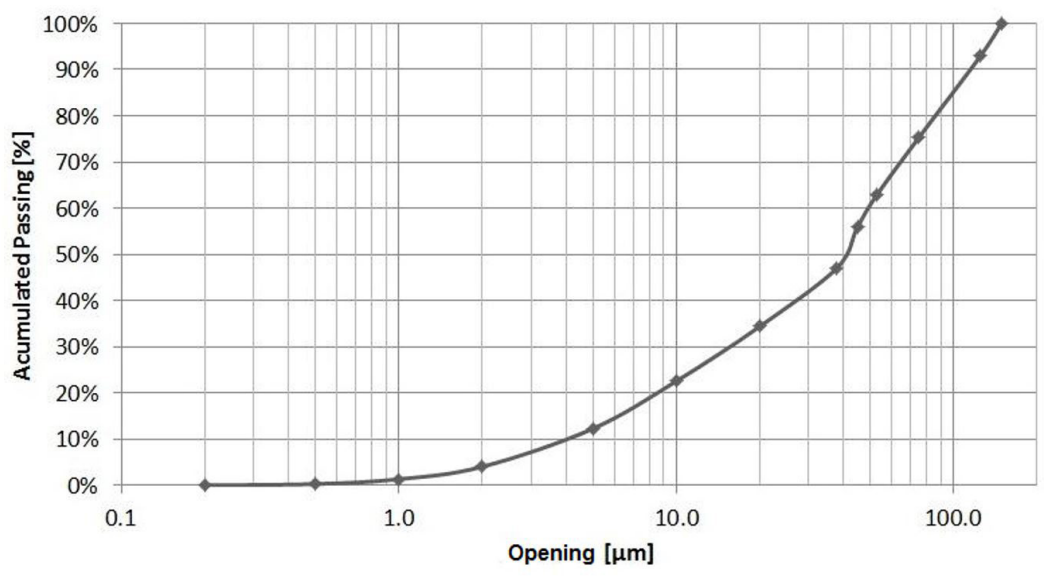

Figure 4. Particle size distribution of the sample.

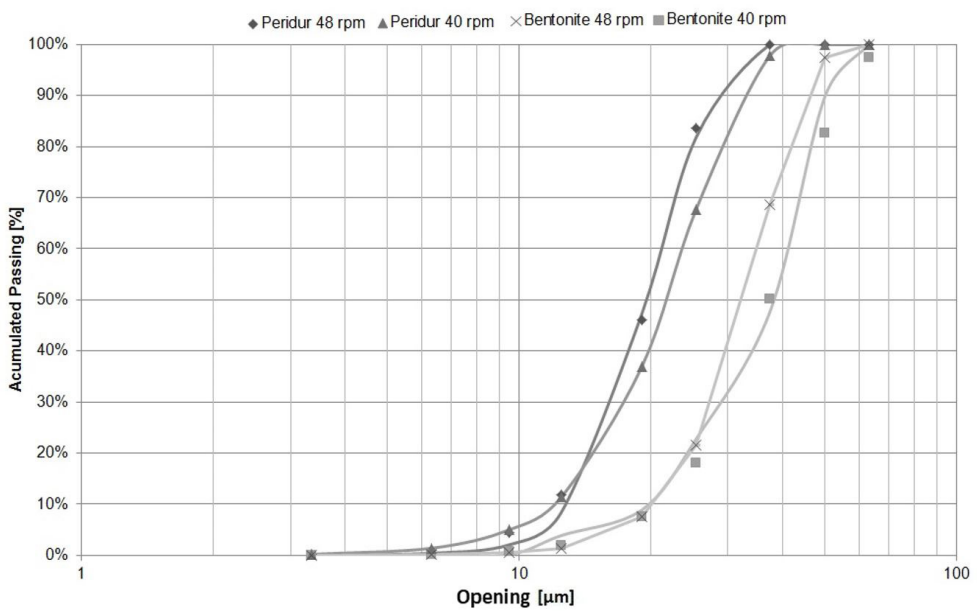

Figure 5. Sieving analysis of the pellets produced.

bentonite, where smaller rotations promoted aggregates with lower moisture (10.7\% for $40 \mathrm{rpm}$ and $14.7 \%$ for $48 \mathrm{rpm})$.

Drop tests were performed with the purpose of measuring the resistance variation of the aggregates according to the granulation time. Bentonite containing pellets resisted to 1.2 falls for 10 minutes and 1.0 falls for 5 minutes. In other hand, Peridur containing pellets resisted to 1.1 falls for 10 minutes and 1.0 falls for 5 minutes. It can be seen from the results that increasing the granulation time lead to an increase in the pellet resistance. This can be credited to the greater consolidation of the pellets with the increase of the residence time.

It is possible to observe that the granules formed in the presence of bentonite presented superior resistance to 

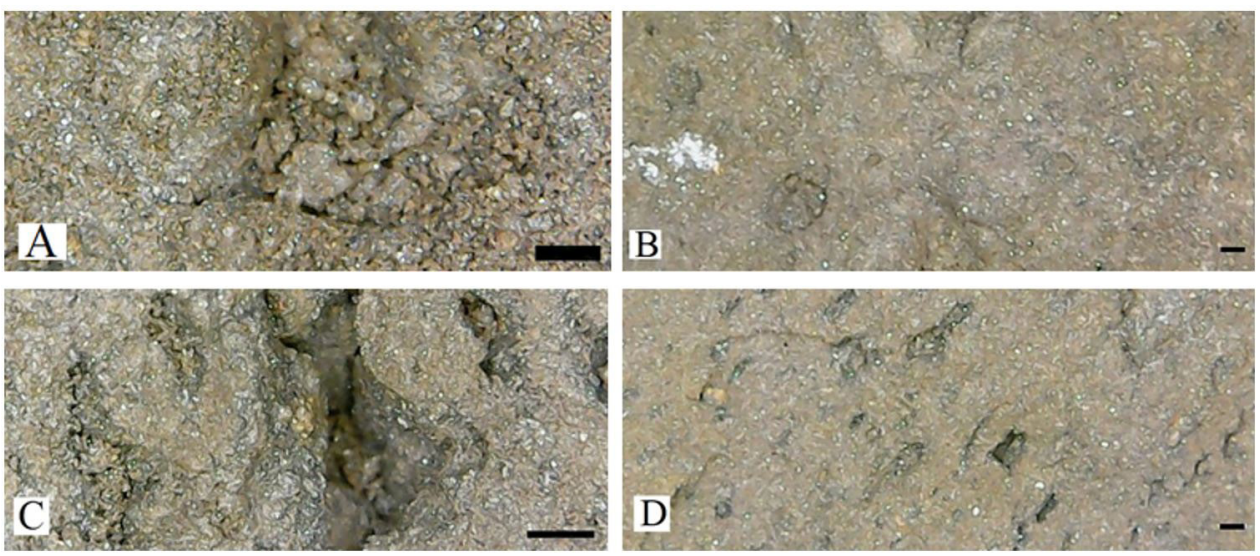

Figure 6. Photomicrographs of pellets produced: (A, B) bentonite; (C, D) Peridur 330 (span between tick marks represent $0.5 \mathrm{~mm}$ in all cases).

Table 4. Specific mass of pellets

\begin{tabular}{cccc}
\hline Binder & True density $\left[\mathbf{k g} / \mathbf{m}^{\mathbf{3}}\right]$ & Bulk density $\left[\mathbf{k g} / \mathbf{m}^{\mathbf{3}}\right]$ & Porosity [\%] \\
\hline Bentonite & 4.374 & 2.981 & 31.9 \\
Peridur 330 & 4.387 & 2.954 & 32.7 \\
\hline
\end{tabular}

Table 5. Permeability constant of the pellets

\begin{tabular}{|c|c|c|c|c|}
\hline \multirow{3}{*}{$\begin{array}{l}\text { Parameter } \\
\text { be identification }\end{array}$} & \multicolumn{4}{|c|}{ Binder } \\
\hline & \multicolumn{2}{|c|}{ Bentonite } & \multicolumn{2}{|c|}{ Peridur 330} \\
\hline & 1 & 2 & 3 & 4 \\
\hline Permeability constant $\left[\mathrm{m}^{2}\right]$ & $8.81 \times 10^{-14}$ & $8.70 \times 10^{-14}$ & $1.33 \times 10^{-13}$ & $1.32 \times 10^{-13}$ \\
\hline Average volumetric flow rate $\left[\mathrm{m}^{3} / \mathrm{s}\right]$ & $2.3 \times 10^{-7}$ & $2.2 \times 10^{-7}$ & $3.24 \times 10^{-7}$ & $3.25 \times 10^{-7}$ \\
\hline Final water height in the pipette [m] & 0.192 & 0.190 & 0.175 & 0.173 \\
\hline
\end{tabular}

Table 3. Bulk density of pellets

\begin{tabular}{ccc}
\hline \multirow{2}{*}{ Assay } & \multicolumn{2}{c}{ Binder } \\
\cline { 2 - 3 } & Bentonite & Peridur 330 \\
\hline Average specific mass $\left[\mathrm{kg} / \mathrm{m}^{3}\right]$ & 2.981 & 2.954 \\
Standard deviation $\left[\mathrm{kg} / \mathrm{m}^{3}\right]$ & 215 & 328 \\
Coefficient of variation $[\%]$ & 7.2 & 11.1 \\
\hline
\end{tabular}

the granules in the presence of the compound Peridur 330. However, for residence times equal to 5 minutes, there was no difference in resistance between the products tested for the same dosage of reagents.

It is possible to observe, through the photomicrographs, a visual difference in the pores of the pellets produced with the two products tested, and that the preparation with the binder Peridur 330 has the deepest pores, which characterizes a lower resistance, however, one can observe more pores than in the bentonite-containing mixture. This behavior can be observed in the micrographies below (Figure 6).

The determination of the actual specific mass of the mixtures was calculated considering the volumetric ratio of each constituent, the following specific masses being considered for the determination of the actual specific mass of the mixture: $2,400 \mathrm{~kg} / \mathrm{m}^{3}$ for bentonite; $2,200 \mathrm{~kg} / \mathrm{m}^{3}$ for hydrated lime; $1,500 \mathrm{~kg} / \mathrm{m}^{3}$ for Peridur 330 (from Akzo Nobel). The calculated results for bulk density are shown in Table 3.
In sequence, the porosity values are presented in Table 4. Mineral mixture containing the bentonite binder presented slightly lower values of porosity than the mixture containing Peridur 330, which corresponds to the higher values of mechanical strength found by drop test.

Permeability experiments were performed (in duplicate) with standardized $10 \mathrm{~mm}$ thick specimens. The following constants were considered: temperature of $298.1 \mathrm{~K}$ $\left(25^{\circ} \mathrm{C}\right)$; initial height of the water column inside pipette equals to $0.23 \mathrm{~m}$; air specific mass equals to $1.3 \mathrm{~kg} / \mathrm{m}^{3}$; and acceleration of gravity equals to $9.81 \mathrm{~m} / \mathrm{s}^{2}$. The results are listed in Table 5.

The mixture containing the bentonite presented slightly lower porosity and lower permeability than the mixture containing Peridur 330, which corresponds to the higher values of resistance found in the bentonite pellets.

\section{Conclusion}

The X-ray diffraction identified hematite and quartz as main minerals and goethite as minor mineral. The chemical analysis quantified, in terms of oxides, the composition of the sample, being hematite $(73.05 \%)$ and quartz $(11.31 \%)$ the major phases. On the other hand, the thermogravimetric analysis identified peaks related to the presence of goethite $(10 \%)$ and kaolinite (3\%), showing the highest precision of 
this method. The pellet feed sample had a specific surface of $1.567 \mathrm{~m}^{2} / \mathrm{g}$ and a true specific mass of $4.502 \mathrm{~kg} / \mathrm{m}^{3}$, which is consistent with the mineralogical and chemical analyses. Sieving analysis has indicated the sample consists of particles below $149 \mu \mathrm{m}$ and $23 \%$ of the sample mass is below $10 \mu \mathrm{m}$.

The rotary drum balling showed dependence on the binders used (bentonite and Peridur 330), the rotational speed of the drum and the granulation time. The use of the blend containing the organic binder Peridur 330 with hydrated lime showed a significant tendency to reduce the average size and increase the regularity of the granules compared to the use of the bentonite blend with hydrated lime. On the other hand, the unit consumption of this reagent is much smaller than that of bentonite, for approximate results.

Drum angular velocity decrease presented a discrete tendency to increase pellet size and the size regularity. As expected, rotation speed closer to half of the critical velocity showed the largest granules formed. The increase in velocity favored the breakage of the aggregates due to the intensity of pellets intercollisions and collisions between pellets and the balling drum wall.
Increasing the granulation time from 5 minutes to 10 minutes showed increased pellet resistance, this effect being more pronounced in the pellets prepared with bentonite. Through the drop test performed, it was possible to observe a higher resistance for the agglomerates prepared with bentonite and under 10 minutes of granulation.

Furthermore, the determination of the actual and apparent specific masses provided also the determination of the porosity of pellets for the two binders tested. Moreover, the bentonite resulted slightly lower porosity and lower permeability, which corresponds to the higher resistance found by drop test.

\section{Acknowledgements}

The authors thank to Brazilian Council for Technological and Scientific Development (CNPq), Foundation for Research Support of the State of Minas Gerais (FAPEMIG) and Brazilian Federal Agency for Support and Evaluation of Graduate Education (CAPES) for their financial support.

\section{References}

1 Litster J, Ennis B. The science and engineering of granulation processes. Brisbane: Springer-Science/Business Media; 2004.

2 Hapgood KP, Iveson SM, Litster JD, Liu LX. Granulation rate processes. In: Salman AD, Hounslow MJ, Seville JP, editor. Granulation. Burlington: Elsevier; 2007.

3 Iveson SM, Litster JD. Fundamental studies of granule consolidation: part 2. Powder Technology. 1998;99:243-250.

4 Moraes SL, Kawatra SK. Evaluation of the use of combinations of binders in the pelletization by balling drum technology. Tecnologica em Metalurgia, Materiais e Mineração. 2011;8(3):168-173.

5 Bragança ACCR. Avaliação de reagentes alternativos para substituição da cal em sistema de bombeamento de longa distância de polpa de minério de ferro [dissertation]. Belo Horizonte: Universidade Federal de Minas Gerais; 2008.

6 Guanzhou Q, Tao J, Li H, Wang D. Functions and molecular structure of organic binders for iron ore pelletization. Colloids and Surfaces A: Physicochem. 2003;224:11-22.

7 Souza AL. Efeito da adição de cal hidratada na etapa de aglomeração das pelotas de minério de ferro produzidas pela Samarco [dissertation]. Belo Horizonte: Universidade Federal de Minas Gerais: 2014.

8 Cameron IT, Wang F, Immanuel CD, Stepanek F. Process systems modelling and applications in granulation: a review. Chemical Engineering Science. 2005;60:3723-3750.

9 Walker GM. Drum granulation processes. In: Salman AD, Hounslow MJ, Seville JP, editor. Granulation. Burlington: Elsevier; 2007.

10 Moraes SL. Contribuição ao entendimento do efeito de agente coloidisante no processo de pelotização de concentrado de minério de ferro [thesis]. São Paulo: University of São Paulo; 2014.

11 Iveson SM, Litster JD, Ennis BJ. Fundamental studies of granule consolidation: part 1. Powder Technology. 1996;88:15-20.

12 Weissenborn PK, Dunn JG, Warren LJ. Quantitative thermogravimetric analysis of hematite, goethite and kaolinite in Western Australian iron ores. Thermochimica Acta. 1994;239:147-156.

13 Garland CW, Nibler JW, Schoemaker DP. Experiments in physical chemistry. New York: McGraw-Hill; 2009.

14 King RP. Modeling and simulation of mineral processing systems. Oxford: Elsevier; 2001.

Received: 26 Jan. 2020

Accepted: 27 Apr. 2021 